\title{
APEX1 wt Allele
}

National Cancer Institute

\section{Source}

National Cancer Institute. APEX1 wt Allele. NCI Thesaurus. Code C50977.

Human APEX1 wild -type allele is located within 14q11.2-q12 and is approximately $13 \mathrm{~kb}$ in length. This allele, which encodes DNA-(apurinic or apyrimidinic site) lyase protein, is involved in DNA repair and the maintenance of DNA integrity. 